\title{
Hydrogen Production and Purification by Bioethanol Steam Reforming and Preferential Oxidation of $\mathrm{CO}$
}

\author{
Producción y Purificación de Hidrógeno por Reformado de Vapor de Bioetanol y Oxidación \\ Selectiva de CO
}

\author{
Juan David Arévalo ${ }^{1 *}$, Ángel Martinez-Hernández ${ }^{2}$, Julio César Vargas ${ }^{1}$, Luis Fernando Córdoba ${ }^{1}$ \\ ${ }^{1}$ Departamento de Ingeniería Química y Ambiental, Universidad Nacional de Colombia, Bogotá, Colombia \\ ${ }^{2}$ Facultad de Ciencias Químicas, Universidad Autónoma de Nuevo León, México
}

\begin{abstract}
Hydrogen production and purification was studied in a combined system including double catalytic bed reaction system. Steam Reforming of Ethanol (SRE) was performed in $\mathrm{Ni} / \mathrm{CeO}_{2}-\mathrm{ZrO}_{2}$ catalyst and, subsequently, the reforming products gases passed through a second fixed bed containing $\mathrm{Au} / \mathrm{CeO}_{2}-\mathrm{ZrO}_{2}$ catalyst in order to carry out the preferential $\mathrm{CO}$ oxidation (PROX-CO). Initially, the effect of temperature and the initial water concentration in the fed ethanol were evaluated to determine the conditions that maximize the $\mathrm{H}_{2} / \mathrm{CO}$ ratio while maintaining $100 \%$ conversion of ethanol. These requirements were accomplished when 25 mole $\% \mathrm{H}_{2} \mathrm{O}$ and 4 mole $\% \mathrm{C}_{2} \mathrm{H}_{5} \mathrm{OH}$ (steam/ethanol molar ratio $=7$ ) were used. The catalyst stability was assessed under these reaction conditions at $600^{\circ} \mathrm{C}$, during more than $160 \mathrm{~h}$ on stream, obtaining ethanol conversions above $99 \%$ during the entire test and $\mathrm{H}_{2}$ productivity close to ideal. In the second part of the work, in order to obtain $\mathrm{H}_{2}$ grade $\mathrm{PEM}$, the effect of $\mathrm{O}_{2}$ concentration in the feed stream on the selective $\mathrm{CO}$ oxidation using $\mathrm{Au}-\mathrm{CZ}$ catalysts was investigated in the temperature range of $50-250^{\circ} \mathrm{C}$. Catalytic stability test was also performed. Characterization techniques: Temperature Programmed Reduction (TPR), X-Ray Diffraction (XRD), SEM-EDX, which confirmed the presence of a strong interaction between the mixed oxide support and the metal. In this study, we show a reaction system with double catalytic fixed bed in which hydrogen is obtained with the specifications required by PEM fuel cell. The tested materials exhibit high activity and selectivity towards hydrogen production and $\mathrm{CO}$ selective oxidation in the range of temperature studied.
\end{abstract}

Keywords: $\mathrm{Ni} / \mathrm{CeO}_{2}-\mathrm{ZrO}_{2}$ catalyst, $\mathrm{Au} / \mathrm{CeO}_{2}-\mathrm{ZrO}_{2}$ catalyst, Steam reforming, Ethanol, Hydrogen production. PROX-CO.

*Corresponding Author.

E-mail: jdarevaloa@unal.edu.co
How to cite: Arevalo J. D., Martinez, A., Vargas, J., Cordoba, L. F., Hydrogen Production and Purification by Bioethanol Steam Reforming and Preferential Oxidation of $\mathrm{CO}$, TECCIENCIA, Vol. 13 No. $25,55-64,2018$

DOI: http://dx.doi.org/10.18180/tecciencia.2018.25.7 


\section{TECCIENCIA}

\section{Resumen}

La producción y purificación de hidrógeno fue estudiada en un sistema combinado incluyendo un doble lecho catalítico. El reformado de etanol con vapor de agua (SER) fue realizado con un catalizador de $\mathrm{Ni} / \mathrm{CeO}_{2}-\mathrm{ZrO}_{2} \mathrm{y}$, posteriormente, los productos gaseosos del reformado pasaron por un segundo lecho catalítico que contiene un catalizador de $\mathrm{Au} / \mathrm{CeO}_{2}-\mathrm{ZrO} \mathrm{r}_{2}$, para llevar a cabo la oxidación preferencial de CO (PROX-CO). Inicialmente, el efecto de la temperatura y la concentración inicial de agua en el alimento de etanol fueron evaluados para determinar las condiciones que maximizan la relación $\mathrm{H}_{2} / \mathrm{CO}$ mientras se mantiene una conversión del $100 \%$ de etanol. Estos requerimientos se lograron con $25 \mathrm{~mol} \% \mathrm{H}_{2} \mathrm{O}$ y $4 \mathrm{~mol} \%$ $\mathrm{C}_{2} \mathrm{H}_{5} \mathrm{OH}$ (vapor de agua/etanol relación molar $=7$ ). La estabilidad catalítica fue evaluada a esas condiciones de reacción a $600^{\circ} \mathrm{C}$, durante más de $160 \mathrm{~h}$, obteniendo conversiones por encima de $99 \%$ en todo el ensayo y una productividad de $\mathrm{H}_{2}$ cercana a la ideal. En la segunda parte del trabajo, para obtener $\mathrm{H}_{2}$ grado PEM, se estudió el efecto de la concentración de $\mathrm{O}_{2}$ en la corriente de alimento a la oxidación selectiva de $\mathrm{CO}$ usando el catalizador $\mathrm{Au}-\mathrm{CZ}$ en el rango de $50-250^{\circ} \mathrm{C}$. La prueba de estabilidad también fue realizada. Técnicas de caracterización: Reducción a Temperatura Programada (TPR), Difracción de Rayos X (XRD), SEM-EDX, las cuales confirmaron la presencia de una fuerte interacción entre el soporte de óxido mixto y el metal. En este estudio, se presenta un sistema de reacción con doble lecho catalítico en el cual el hidrógeno es obtenido con las especificaciones requeridas por las celdas de combustible PEM. Los materiales ensayados exhibieron una alta actividad y selectividad hacia la producción de hidrógeno y oxidación selectiva de $\mathrm{CO}$ en el rango de temperatura evaluado.

Palabras clave: Catalizador $\mathrm{Ni} / \mathrm{CeO}_{2}-\mathrm{ZrO}_{2}$, Catalizador $\mathrm{Au} / \mathrm{CeO}_{2}-\mathrm{ZrO}_{2}$, Reformado de vapor, Etanol, Producción de Hidrógeno, PROX-CO.

\section{Introduction}

Sustainable energy means that human activities achieve a balance among economic, social, and environmental needs, covering the current requirements without harming the ability of future generations [1]. Most of the energy used today comes from fossil fuels, a non-renewable resource that has caused serious environmental problems, which have motivated the development of alternative energy sources, such as solar, wind, and biomass energies. Recently, environmental regulations have increased the production of biofuels as an alternative energy source and, in this context, hydrogen $\left(\mathrm{H}_{2}\right)$ production from ethanol has been identified as an ideal energy carrier for the short-term [2] [3]. Currently, $\mathrm{H}_{2}$ is mainly produced from steam reforming of fossil fuels, however, the production of hydrogen from natural gas is always associated with the emission of greenhouse gases and local pollutant [4] [5]. Therefore, it is highly desirable to incorporate renewable sources for $\mathrm{H}_{2}$ generation to develop a more sustainable energy model. The Steam Reforming of Ethanol (SRE) is one of the most promising methods for $\mathrm{H}_{2}$ generation, because it can produce more $\mathrm{H}_{2}$ per mole of ethanol than other methods [6].

In addition, the most promising application for $\mathrm{H}_{2}$ as a power energy is a Proton-Exchange Membrane (PEM) fuel cell technology. Fuel cells not only eliminate toxic emissions, but also have a higher efficiency than internal combustion engines for converting the chemical energy of the fuel to electrical energy [7].
Currently, the commercially available and reliable PEMs convert directly the hydrogen into electricity, hence a fuel processing unit is required in order to transform the energy content of the ethanol into a hydrogen-rich stream [8]. Besides hydrogen, SRE also produces a small amount of CO (about 1\%) that reduces the energy efficiency of the PEM fuel cell.

Since the electrodes of the fuel cell are typically made of platinum, which is very sensitive to $\mathrm{CO}$ poisoning, the $\mathrm{CO}$ concentration must be below $10 \mathrm{ppm}$ [9]. Several methods for the removal of carbon monoxide exist, such as the preferential $\mathrm{CO}$ oxidation (PROX-CO), selective $\mathrm{CO}$ methanation, and selective diffusion through membranes. However, the preferential oxidation of $\mathrm{CO}$ (PROX-CO) is the most efficient and economic method [10] [11].

The design of an appropriate catalyst system for simultaneous catalytic reforming and PROX-CO allows to improve the overall efficiency of the fuel cells [11]. The nature of the support also plays an important role towards product selectivity and the deactivation behavior of the catalyst. Acidic supports like $\mathrm{Al}_{2} \mathrm{O}_{3}$ are more prone to deactivation on account of coke formation [12]. Suitable basic supports, such as $\mathrm{CeO}_{2}$ and $\mathrm{La}_{2} \mathrm{O}_{3}$ or mixed oxides, can inhibit carbon deposition to some extent [6] [13]. $\mathrm{CeO}_{2}$ has been broadly reported as an active support for both steam reforming and oxidation catalysts due to its structural properties [14] [15]. This oxide has a redox behavior that allows high oxygen mobility and enhance the oxygen exchange with the medium [16]. 


\section{TECCIENCLA}

Additionally, it has been found that the addition of $\mathrm{ZrO}_{2}$ improves the redox properties, thus, oxygen mobility can be improved throughout the generation of a mixed system with a strong interaction, preferably as a solid solution in order to promote electronic distortions in the oxide framework. $\mathrm{CeO}$ 2 also contributes to homogeneous dispersion of the metal, stability of the catalyst to high reaction times and temperatures, and reduces the sintering problems in the catalyst [7] [13] [17]. Biswas and Kunzru [13] studied the SRE for hydrogen production over $\mathrm{Ni} / \mathrm{Ce}_{1-\mathrm{x}} \mathrm{Zr}_{\mathrm{x}} \mathrm{O}_{2}(\mathrm{x}=0$, $0.26,0.59,0.84$ and 1) catalyst. They reported that $\mathrm{Ni} / \mathrm{Ce}_{0.74} \mathrm{Zr}_{0.26} \mathrm{O}_{2}$ catalyst with $30 \mathrm{wt} \%$ metal load exhibited high catalytic activity and hydrogen selectivity (5.8 mole $/$ mole of ethanol reacted) at a temperature of $600^{\circ} \mathrm{C}$. At this temperature, the ethanol conversion was $100 \%$ and $\mathrm{CO}$ selectivity was 0.47 . They suggest that the reason for the high activity could be the high oxygen storage capacity of cubic $\mathrm{Ce}_{0.74} \mathrm{Zr}_{0.26} \mathrm{O}_{2}$.

Noble metal catalysts based on $\mathrm{Pt}, \mathrm{Rh}, \mathrm{Ru}, \mathrm{Au}$ [5] have showed good catalytic activity and resistance for SRE. Nonetheless, their main disadvantage is their high cost and the relatively low availability of noble metals. Among nonnoble metals, $\mathrm{Ni}$ and $\mathrm{Co}$ are the most used in steam reforming processes [12] [18] [19] [20] [21] [22] [23]. Nisupported catalysts showed good ethanol conversions and good selectivity for hydrogen production. However, the main drawback of these catalysts is their relatively poor stability in time, as the catalyst deactivation occurs mainly by carbon deposition. An option to improve the Ni-based catalysts activity and to diminish the catalyst deactivation is promotion with other elements. Promotion of Ni-based catalysts with rare earth oxides proved their efficiency for steam and, thus, these oxides were identified as promoters of carbon removal from the catalysts [24] [25]. Likewise, gold supported catalysts are more active and selective in the $\mathrm{CO}$ conversion at low temperature, than other noble metals [16] [26]. Haruta and coworkers [27] showed that gold nanoparticles with a diameter between 2 and $4 \mathrm{~nm}$ are very effective for the CO oxidation. Several factors, such as the size of the gold particle, its oxidation state [28] [29] and the nature of the support [30] [31] affect the catalytic activity in the PROX-CO reaction at low temperatures in the presence of $\mathrm{H}_{2}$. In this way, the choice of the synthesis method is crucial to control all these factors.

Therefore, the aim of this work is to obtain CO-free hydrogen suitable for fuel cell (PEM). For this purpose, a reaction system with double catalytic bed was used: the steam reforming of ethanol (SRE) was studied using $\mathrm{Ni} / \mathrm{CeO}$ ${ }_{2}-\mathrm{ZrO}_{2}$ catalyst $(\mathrm{Ni}-\mathrm{CZ})$ and, subsequently, the reforming products gases passed through a second fixed bed reactor containing $\mathrm{Au} / \mathrm{CeO}_{2}-\mathrm{ZrO}_{2}$ catalyst (Au-CZ) in order to carry out the selective $\mathrm{CO}$ oxidation (PROX-CO).
Initially, the effect of the temperature and the initial concentrations of ethanol and water were evaluated at space velocities above $55,000 \mathrm{~h}^{-1}$ to determine the conditions that maximize the $\mathrm{H}_{2} / \mathrm{CO}$ ratio. Conversion of ethanol was kept at $100 \%$ and the catalyst stability was evaluated at $600^{\circ} \mathrm{C}$, during more than $160 \mathrm{~h}$ on stream. In the second part of the work, in order to obtain $\mathrm{H}_{2}$ grade PEM, the effects of $\mathrm{O}_{2}$ concentration in feed stream on the selective $\mathrm{CO}$ oxidation with $\mathrm{Au}-\mathrm{CZ}$ catalysts were studied in the temperature range of $50-250^{\circ} \mathrm{C}$. Catalytic stability test was also performed.

\section{Experimental method}

\subsection{Catalyst preparation}

The fluorite oxides $\mathrm{Ni} / \mathrm{Ce}_{0.75} \mathrm{Zr}_{0.25} \mathrm{O}_{2} \quad$ (Ni-CZ) were synthesized by a pseudo sol-gel method, based on the thermal decomposition of propionate precursors [32] [33] [34]. Ni load was applied in 3\%, 5\% and $7 \mathrm{wt} \%$, resulting in catalytic systems labeled $\mathrm{CZ}, 3 \mathrm{Ni}-\mathrm{CZ}, 5 \mathrm{Ni}-\mathrm{CZ}$ and $7 \mathrm{Ni}-\mathrm{CZ}$, respectively. The precursor materials for $\mathrm{Ce}, \mathrm{Zr}$ and $\mathrm{Ni}$ were cerium (III) acetate sesquihydrate, zirconium (IV) acetylacetonate and nickel (II) acetate tetrahydrate. These salts were separately dissolved in boiling propionic acid using a concentration of $0.12 \mathrm{~mol}^{-1}$ in cation, at $100^{\circ} \mathrm{C}$ for $1 \mathrm{~h}$, leading exclusively to propionate precursors. The three boiling solutions were mixed during $2 \mathrm{~h}$ under reflux and, then, the solvent was evaporated until resin was obtained. Finally, the resin was calcined under air at $500^{\circ} \mathrm{C}$ for $6 \mathrm{~h}$, with a heating ramp of $2^{\circ} \mathrm{C} \mathrm{min}^{-1}$. To load gold, the procedure reported by Lin et al. was followed [35]. A suitable amount of chloroauric acid $\left(\mathrm{HAuCl}_{4} \bullet 3 \mathrm{H}_{2} \mathrm{O}\right)$ was dissolved in $250 \mathrm{ml}$ of stirred deionized water and sodium hydroxide solution was added for adjusting the solution $\mathrm{pH}$ at 6 . Then, $2 \mathrm{~g}$ of $\mathrm{Ce}-\mathrm{Zr}$ oxide were added, followed by heating the solution to $80^{\circ} \mathrm{C}$ and mixing it for 2 hours. After filtration and washing until $\mathrm{Cl}^{-}$ions-free, the resulted gold samples were dried at $60^{\circ} \mathrm{C}$ for $12 \mathrm{~h}$ under air.

\subsection{Catalysts characterization}

\subsubsection{ICP-AES and EDX}

The Ni and gold load of fresh catalyst was determined by Inductively Coupled Plasma Atomic Emission Spectroscopy (ICP-AES, Perkin Elmer Optima 3300DV).

\subsubsection{Temperature Programmed Reduction (TPR)}

$\mathrm{H}_{2}$ - TPR experiments were performed in home-made equipment. A sample of $50 \mathrm{mg}$ was reduced by flowing 25 $\mathrm{cm}^{3} / \mathrm{min}$ of $5 \% \mathrm{H}_{2}$ in $\mathrm{Ar}$ through the reactor. The temperature of the reactor was raised from room temperature up to $900^{\circ} \mathrm{C}$ at a heating rate of $10^{\circ} \mathrm{C} / \mathrm{min}$. 


\section{TECCIENCIA}

Hydrogen consumption was measured by means of a Thermal Conductivity Detector (TCD). A desiccant (silica gel) trap was used to retain the $\mathrm{H}_{2} \mathrm{O}$ produced during the reduction reaction between the oxides on the catalyst and the $\mathrm{H}_{2}$ of the reaction stream.

\subsubsection{X-Ray Diffraction (XRD)}

Powder X-Ray Diffraction (XRD, Siemens D-5000) patterns were used to obtain information about the structure and composition of crystalline materials

\subsubsection{BET surface area}

The Brunauer-Emmett-Teller (BET) method was used to determine the surface area and pore size of the catalysts by $\mathrm{N}_{2}$ adsorption/desorption at $77 \mathrm{~K}$. Specific surface area was determined using an Asap 2020 surface area analyzer and Quantachrome Autosorb-1.

\subsubsection{Scanning Electron Microscopy (SEM)}

The morphology, shape and dimensions of prepared calcined catalyst powders were analyzed using a Scanning Electron Microscopy (SEM) JSM-6490LV equipped with Energy Dispersive X-ray (EDX) analyzer and SEM images were obtained.

\subsection{Activity measurement}

The effects of temperature, the initial concentrations of water and ethanol in SRE and the effect of $\mathrm{O}_{2}$ concentration on PROX-CO were tested. For the test, two tubular reactors in series were used. SRE was conducted at atmospheric pressure in a quartz, U-shaped, $6 \mathrm{~mm}$ ID fixed bed reactor located in an electric furnace.

The catalyst $\mathrm{Ni}-\mathrm{CZ}$ was heated from room temperature to the reaction temperature $\left(500-700^{\circ} \mathrm{C}\right)$ under a flow of $\mathrm{He}$ gas controlled by Brooks Electronic gas flow meters. The reactant flow added to the inert stream was a liquid mixture of ethanol: water (steam to ethanol molar ratio, $\mathrm{S} / \mathrm{E}=3-7$ ) pumped into the system using a 303 Gilson HPLC pump and introduced into the reactor using a needle device.

The steady state condition was reached approximately after 30 min of reaction. The carbon balance was close to $95 \%$ in all the experiments. The Gas Hourly Space Velocity (GHSV) was calculated by the flow rate input (Fo, L/min) at standard conditions divided by the catalytic bed volume (V, $\mathrm{L})$. The catalysts were reduced in situ, prior to reaction, in a stream of $\mathrm{H}_{2}$ for $3 \mathrm{~h}$ with a total flow gas of $45 \mathrm{ml} \mathrm{min}^{-1}$ at $700^{\circ} \mathrm{C}$ and a heating ramp of $5^{\circ} \mathrm{C} \mathrm{min}^{-1}$.
PROX-CO reactions were carried out in a system similar to the SRE reaction. Air was added to the effluent gases from the SRE, before entering the PROX-CO reactor, and the individual stream flow rate was controlled by mass flow controllers to achieve $\mathrm{O}_{2}$ concentration between 1 and $2 \%$.

The reactor effluent was analyzed by an in-line assembly of two, in series, gas chromatographs. The first one was a GC HP 5890 series II equipped with a HP-PLOT/Q column (0.53 mm ID and $30 \mathrm{~m}$ length, Agilent Technologies, USA) for $\mathrm{CO}_{2}$, ethanol, and acetaldehyde. The second one was a GC HP 5890 A equipped with a Molecular Sieve 5A column (Agilent Technologies, USA) for $\mathrm{H}_{2}, \mathrm{O}_{2}, \mathrm{CH}_{4}$, and $\mathrm{CO}$. The selectivity of $\mathrm{CO}$ oxidation was defined as the oxygen consumption during $\mathrm{CO}$ oxidation divided by the total oxygen consumption. There was no methane formation under the reaction conditions on $\mathrm{PROX}-\mathrm{CO}$ reactor.

\section{Results}

\subsection{Chemical and textural analysis}

BET surface areas of the support $\mathrm{CeO}_{2}-\mathrm{ZrO}_{2}$, and the catalysts $\mathrm{Ni} / \mathrm{CeO}_{2}-\mathrm{ZrO}_{2}$ and $\mathrm{Au} / \mathrm{CeO}_{2}-\mathrm{ZrO}_{2}$ are given in Table 1. The surface area of the support $\mathrm{CZ}$ was $38.1 \mathrm{~m} 2 / \mathrm{g}$ and decreased after metal impregnation.

These results suggest that the incorporation of metal significantly reduced the surface of the support, as reported by others [13] [15]. Presumably, the area reduction is due to the partial blockage of the pore surface by metal oxide particles. However, it can be observed that the surface area increases as Ni load increases.

\subsection{ICP-AES and EDX}

The compositions of the calcined catalysts, determined by ICP-AES and Energy Dispersive X-ray (EDX) coupled to SEM techniques, are shown in Table 1.

Table 1 Catalyst surface area and metal loading on various catalysts

\begin{tabular}{|c|c|c|c|c|c|}
\hline \multirow[t]{2}{*}{ Catalyst } & \multirow[t]{2}{*}{$\begin{array}{l}\text { BET } \\
\text { surface } \\
\text { area }\left(\mathrm{m}^{2} / \mathrm{g}\right)\end{array}$} & \multirow[t]{2}{*}{$\begin{array}{l}\text { Metal loading }{ }^{\mathrm{a}} \\
\text { (wt \%) }\end{array}$} & \multicolumn{3}{|c|}{$\begin{array}{l}\text { Metal loading } \\
\text { (wt \%) }\end{array}$} \\
\hline & & & $\begin{array}{l}\text { Point } \\
1\end{array}$ & $\begin{array}{l}\text { Point } \\
2\end{array}$ & $\begin{array}{l}\text { Point } \\
3\end{array}$ \\
\hline $\mathrm{CZ}$ & 38.1 & - & - & - & - \\
\hline $3 \mathrm{Ni}-\mathrm{CZ}$ & 12.2 & 3.5 & 2.38 & 2.56 & 3.32 \\
\hline $5 \mathrm{Ni}-\mathrm{CZ}$ & 14.6 & 4.48 & 4.52 & 4,48 & 4.63 \\
\hline 7Ni-CZ & 23.7 & 7.7 & 6.36 & 5.77 & 7.71 \\
\hline $2 \mathrm{Au}-\mathrm{CZ}$ & 31.2 & 2.1 & - & - & - \\
\hline
\end{tabular}




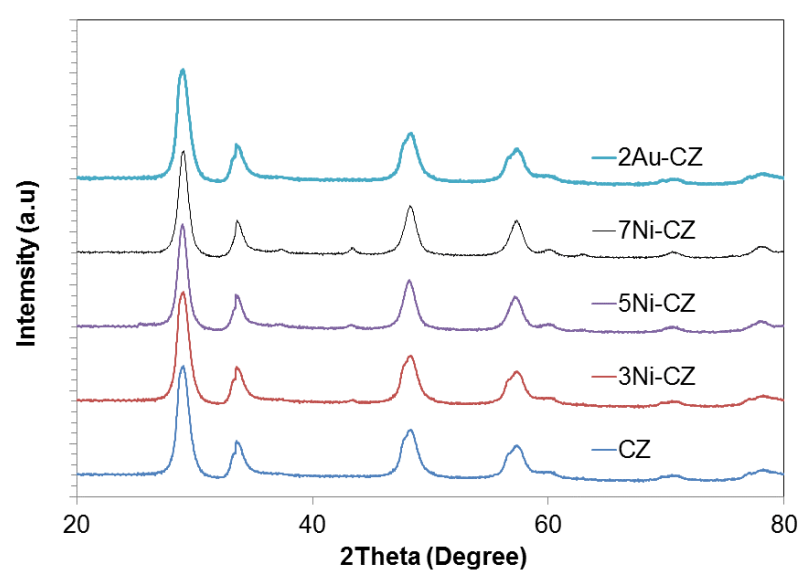

Figure 1 XRD Patterns of Ni-CZ and Au-CZ catalyst.

The measured compositions were close to experimental metal load. Furthermore, the EDX analysis of nickel catalyst performed in different points of the sample suggest that nickel concentration is homogeneously dispersed on the support.

\section{$3.3 X R D$}

Fig. 1 shows the XRD patterns of $\mathrm{Ni}-\mathrm{CZ}$ and $\mathrm{Au}-\mathrm{CZ}$ catalysts. The samples clearly evidenced the reflections

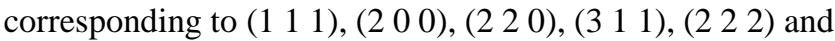
(4 0 0) planes of the $\mathrm{Ce}_{0.75} \mathrm{Zr}_{0.25} \mathrm{O}_{2}$ fluorite cubic structure (JCPDS Card No. 28-0271). In addition, no segregation phases of $\mathrm{CeO}_{2}$ or $\mathrm{ZrO}_{2}$ were detected; hence, $\mathrm{ZrO}_{2}$ is totally incorporated into the $\mathrm{CeO}_{2}$ lattice to form a homogeneous solid solution. [32] [33]. The results agree with those reported by Biswas and Kunzru [13] who prepared and characterized $\mathrm{Ce}_{1-\mathrm{x}} \mathrm{Zr}_{\mathrm{x}} \mathrm{O}_{2}$ catalyst with different $\mathrm{Ce} / \mathrm{Zr}$ ratios $(\mathrm{x}=0,0.26,0.59,0.84$ and 1$)$. They reported that diffraction peaks of $\mathrm{ZrO}_{2}$ were not observed up to a $\mathrm{ZrO}_{2}$ content of $59 \%$, when $\mathrm{Zr}$ content increased to $84 \%$. The peaks due to the crystal plane of $\mathrm{ZrO}_{2}$ were clearly observed, suggesting the incorporation of $\mathrm{ZrO}_{2}$ into the $\mathrm{CeO}_{2}$ lattice to form a solid solution.

\section{$3.4 T P R$}

The reduction profile of pure $\mathrm{CeO}_{2}$ is characterized by two peaks (not shown) widely reported [13] [36] [37]: one at low temperature centered at $503^{\circ} \mathrm{C}$, which is generally attributed to the reduction of the surface layer of $\mathrm{CeO}_{2}$, and another small peak at a higher temperature centered around $752^{\circ} \mathrm{C}$, which is attributed to the reduction of the material in the bulk. In the case of pure $\mathrm{ZrO}_{2}$, the TPR pattern did not show any evident reduction peak. Furthermore, for the studied support $\mathrm{CeO}_{2}-\mathrm{ZrO}_{2}$, the reduction peak at higher temperature was not present (Fig. 2).

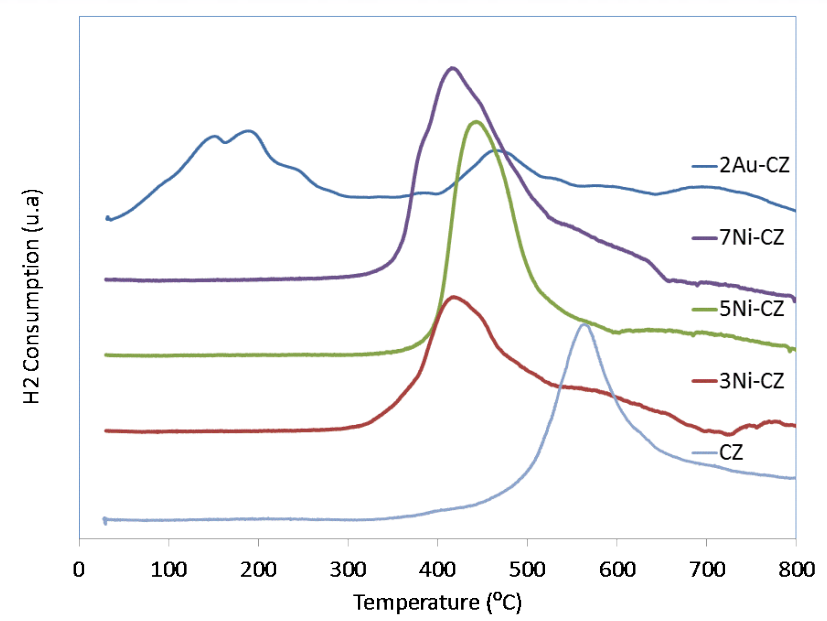

Figure 2 TPR profile.

This indicates that in the presence of $\mathrm{ZrO}_{2}$, the bulk reduction of $\mathrm{CeO}_{2}$ does not occur easily, most probably because the interaction between $\mathrm{CeO}_{2}$ and $\mathrm{ZrO}_{2}$ formed a solid solution, such as suggested by Biswas el at [13].

The TPR profile of unsupported $\mathrm{NiO}$ shows a board peak between $370^{\circ} \mathrm{C}$ and $420^{\circ} \mathrm{C}$, which indicates the complete reduction of $\mathrm{NiO}$ [15] [21]. For $\mathrm{Ni}-\mathrm{CZ}$, a broad peak appears in the range from 350 to $550^{\circ} \mathrm{C}$, however, the maximum peak around $580^{\circ} \mathrm{C}$ observed in $\mathrm{CZ}$ support disappears in all the supported Ni catalysts. It seems that the peak corresponding to $\mathrm{Ce}-\mathrm{ZrO}_{2}$ shifts to lower temperatures and, thus, overlaps the $\mathrm{NiO}$ reduction peak.

Dong et al. [21] obtained similar results with $\mathrm{Ni} / \mathrm{Ce}-\mathrm{ZrO}_{2}$ and they explain that a strong interaction of $\mathrm{Ni}$ incorporation into $\mathrm{Ce}-\mathrm{ZrO}_{2}$ makes ceria more reducible, which helps to produce mobile oxygen during the reforming reaction. It also can be noted that the intensity for the reduction peak of $\mathrm{Ni}-\mathrm{CZ}$ catalyst increased significantly, indicating that the presence of $\mathrm{Ni}$ enhanced the reducibility $\mathrm{CZ}$ support. In another work, Moretti et al. [18] reported the multiplicity of reduction peaks at low temperatures with $\mathrm{Ni}$ samples, and they attributed it to the low interaction of the reduction of $\mathrm{NiO}$ with the support. Thus, the absence of reduction peaks at low temperature is in agreement with the XRD result showing the high nickel dispersion strongly interacting with the support.

\subsection{Scanning Electron Microscopy (SEM)}

SEM image of $7 \mathrm{Ni}-\mathrm{CZ}$ are shown in Fig. 3. It shows that metal particles are uniformly dispersed on the $\mathrm{CZ}$ support. The $\mathrm{NiO}$ crystallite sizes in the prepared (fresh) catalysts are less than $100 \mathrm{~nm}$ with the exception of a few larger particles, which is in agreement with the results obtained from XRD data. 


\section{TECCIENCIA}

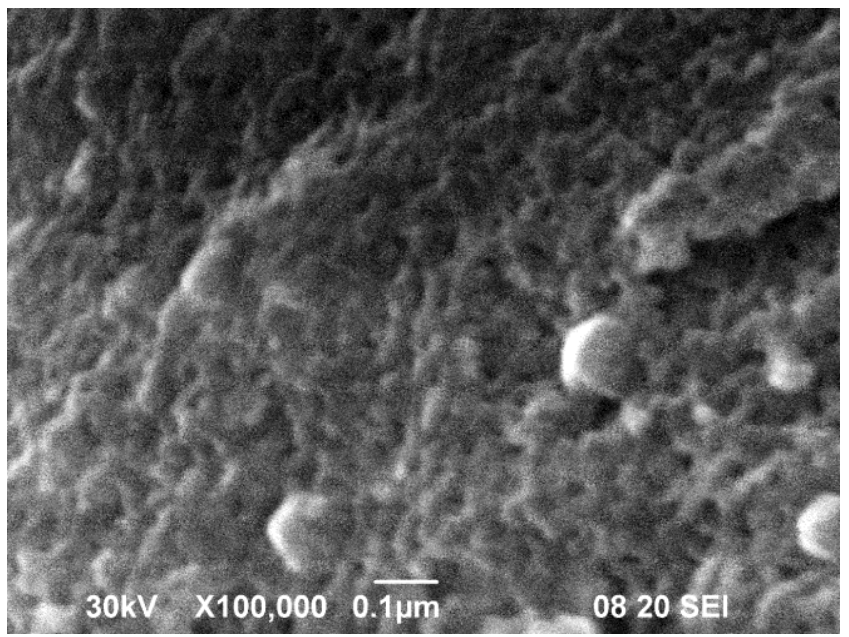

3.6 Catalytic activity

3.6.1 Steam reforming of ethanol

Blank tests in an empty reactor (thermal homogeneous reaction) of the reaction system, under the same conditions as the catalytic tests, were presented in a previous study [6]. The ethanol conversion was over $90 \%$ in the blank test, and although some $\mathrm{H}_{2}, \mathrm{CH}_{4}, \mathrm{CO}$, and $\mathrm{CO}_{2}$ appeared at higher temperatures, the product distribution agreed with the decomposition and dehydration reaction, and the coke formation took place. Table 2 summarizes the effect of the Ni load over Ni-CZ during the SRE, as well as the effect of water on the SRE for a $4 \%$ mol ethanol sample.

Figure 3 image of $7 \mathrm{Ni} / \mathrm{CeO}_{2}-\mathrm{ZrO}_{2}$ catalyst.

Table 2 Catalytic test for steam reforming of ethanol.

\begin{tabular}{|c|c|c|c|c|c|}
\hline $\begin{array}{l}\text { Catalyst } \\
\text { sample }\end{array}$ & $\begin{array}{l}\text { S/E } \\
\text { Ratio }\end{array}$ & $\begin{array}{l}\text { water (molar } \\
\text { fraction) }\end{array}$ & $\begin{array}{l}\mathrm{T} \\
\left({ }^{\circ} \mathrm{C}\right)\end{array}$ & $\begin{array}{l}\text { Ethanol conversion } \\
(\%)\end{array}$ & $\begin{array}{l}\text { Mole } \mathrm{H}_{2} / \\
\text { mole ethanol consumed }\end{array}$ \\
\hline \multirow{10}{*}{$3 \mathrm{Ni}-\mathrm{CZ}$} & \multirow{3}{*}{$3: 1$} & \multirow{3}{*}{0.12} & 500 & 96.7 & 1.33 \\
\hline & & & 600 & 100 & 2.56 \\
\hline & & & 700 & 100 & 4.1 \\
\hline & \multirow{4}{*}{$5: 1$} & \multirow{4}{*}{0.20} & 500 & 98.2 & 1.49 \\
\hline & & & 600 & 100 & 3.05 \\
\hline & & & 700 & 100 & 3.9 \\
\hline & & & 500 & 100 & 2.23 \\
\hline & \multirow[t]{3}{*}{$7: 1$} & \multirow[t]{3}{*}{0.25} & 600 & 100 & 3.82 \\
\hline & & & 700 & 100 & 4.9 \\
\hline & & & 500 & 98.2 & 1.39 \\
\hline \multirow{8}{*}{$5 \mathrm{Ni}-\mathrm{CZ}$} & \multirow[t]{3}{*}{$3: 1$} & \multirow[t]{3}{*}{0.12} & 600 & 100 & 2.84 \\
\hline & & & 700 & 100 & 4.47 \\
\hline & & & 500 & 97.7 & 1.59 \\
\hline & \multirow[t]{3}{*}{$5: 1$} & \multirow[t]{3}{*}{0.20} & 600 & 100 & 3.54 \\
\hline & & & 700 & 100 & 4.69 \\
\hline & & & 500 & 100 & 2.49 \\
\hline & \multirow[t]{3}{*}{$7: 1$} & \multirow[t]{3}{*}{0.25} & 600 & 100 & 4.46 \\
\hline & & & 700 & 98.5 & 5.4 \\
\hline \multirow{9}{*}{ 7Ni-CZ } & & & 500 & 98.5 & 1.46 \\
\hline & \multirow[t]{3}{*}{$3: 1$} & \multirow[t]{3}{*}{0.12} & 600 & 100 & 3.02 \\
\hline & & & 700 & 100 & 5.2 \\
\hline & & & 500 & 98.2 & 2.62 \\
\hline & \multirow[t]{3}{*}{$5: 1$} & \multirow[t]{3}{*}{0.20} & 600 & 100 & 4.2 \\
\hline & & & 700 & 100 & 5.5 \\
\hline & & & 500 & 100 & 3.06 \\
\hline & \multirow[t]{2}{*}{$7: 1$} & \multirow[t]{2}{*}{0.25} & 600 & 100 & 5.39 \\
\hline & & & 700 & 100 & 5.6 \\
\hline
\end{tabular}




\section{TECCIENCIA}

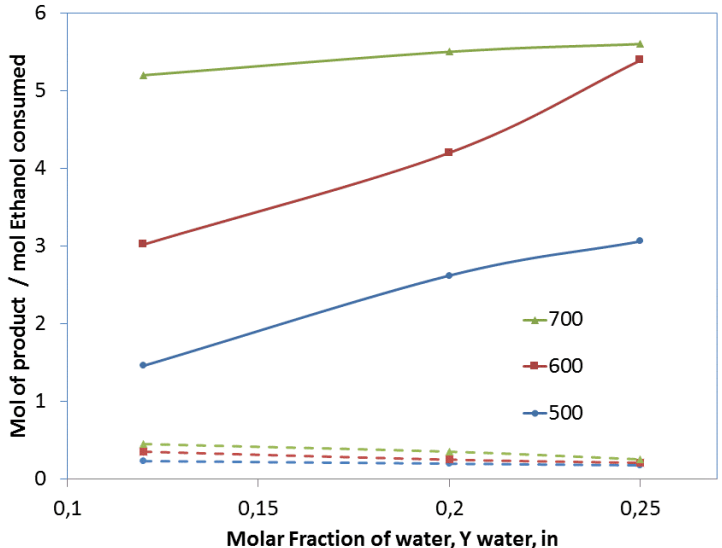

Figure 4 Selectivity of $\mathrm{H}_{2}$ and $\mathrm{CO}$ vs. water molar fraction and temperature in the steam reforming of ethanol over the $7 \mathrm{Ni} / \mathrm{CeO}_{2}-\mathrm{ZrO}_{2}$ catalyst. For reaction conditions refer to Table 1.

Fig. 4 displays the product distribution after the SRE at different temperatures when $\mathrm{H}_{2} \mathrm{O}$ was varied from 12 to 25 mol\% for $7 \mathrm{Ni}-\mathrm{CZ}$, which shows the best performance. In Table 2, it is appreciated that the maximum hydrogen production approach to equilibrium 5.9 mole per mole of ethanol consumed was obtained with the catalyst $7 \mathrm{Ni}-\mathrm{CZ}$ at $700^{\circ} \mathrm{C}$ and $\mathrm{S} / \mathrm{E}=7$, and for these conditions the ethanol conversion was $100 \%$. According to the thermodynamics of the reaction, $\mathrm{H}_{2}$ production is favored at high temperatures by an excess of water. Sun et al. [38] reported the highest $\mathrm{H}_{2}$ yield and lower $\mathrm{CO}$ production at $\mathrm{T}>627^{\circ} \mathrm{C}$ and $\mathrm{S} / \mathrm{E}>6$ in the thermodynamic analysis of the SRE. Otherwise, it has been reported that using $\mathrm{Ni}(\mathrm{II})-\mathrm{Al}(\mathrm{III})$ layered catalyst can be found an ethanol/water molar ratio that maximizes the ethanol conversion [6] [39] That decrease was attributed to a competition between ethanol and water for the same active sites. As observed in Fig 4, $\mathrm{H}_{2}$ yields continuously increased with $\mathrm{H}_{2} \mathrm{O}$ and temperature. Since there is not a significant difference in hydrogen production between $600^{\circ} \mathrm{C}$ and $700^{\circ} \mathrm{C}$ at 25 mole $\%$ of water, $600^{\circ} \mathrm{C}$ was selected as the temperature for stability test, considering additional energy requirements

\subsubsection{PROX-CO}

Fig 5 shows the effect of the pretreatments on the activity and selectivity of $2 \mathrm{Au}-\mathrm{CZ}$ catalyst. Before reaction, the catalyst was activated by oxidation (Oxd) in air at $300^{\circ} \mathrm{C}$ for $1 \mathrm{~h}$ or by reduction (Red) in a $10 \% \mathrm{H}_{2} / \mathrm{He}$ mixture at $300^{\circ} \mathrm{C}$ for $1 \mathrm{~h}$. It is noteworthy that both oxidative and reductive treatments lead to a similar catalytic behavior, since the light-off curves in both cases begin at $50^{\circ} \mathrm{C}$ and the conversion increased with the temperature until it reached a maximum of $99 \%$ and $95 \%$ at $100^{\circ} \mathrm{C}$, with oxidative and reductive pretreatment, respectively.

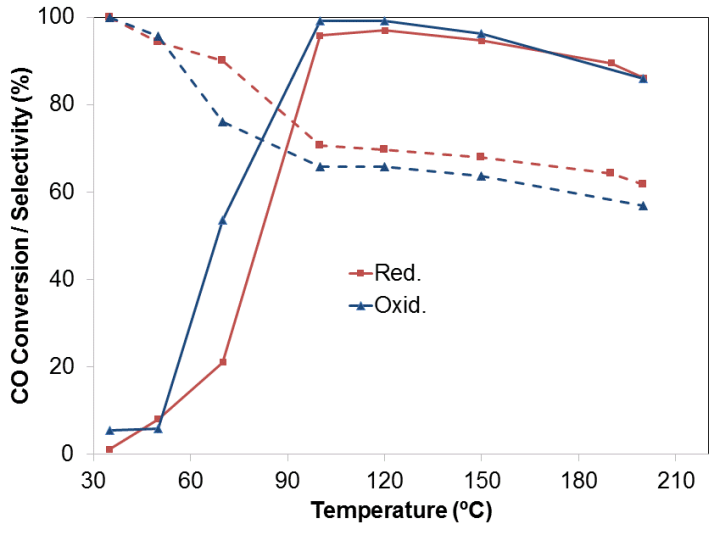

Figure 5 Effect of pretreatment. Reactant composition: 2\% CO. $2 \% \mathrm{O}_{2} .50 \% \mathrm{H}_{2}$ and helium. Selectivity (dotted line); $\mathrm{CO}$ conversion (full line). Catalyst $\mathrm{Au} / \mathrm{CeO}_{2}-\mathrm{ZrO}_{2}$.

This temperature is the most suitable temperature for the fuel cell operating conditions, and thereafter a slightly decrease was observed as the temperature of the reactor increased, indicating the activation of $\mathrm{H}_{2}$ oxidation reaction that competes with the oxidation of $\mathrm{CO}$ [40].

The oxidative pretreatment was selected considering that the nature of the reduced active sites leads a deactivated of the catalyst under the reaction stream [41] The nature of the reduced active sites makes the catalyst more vulnerable to be deactivated under the reaction stream.

The $\mathrm{CO}$ conversion and selectivity as a function of $\mathrm{O}_{2}$ concentration in the feed for the $2 \mathrm{Au}-\mathrm{CZ}$ catalyst is shown in Figures $6 \mathrm{a}$ and $6 \mathrm{~b}$. As expected, the $\mathrm{CO}$ conversion (Fig. 6a) and the selectivity (Fig. 6b) strongly dependence on the $\mathrm{O}_{2}$ concentration. The catalytic activity rises with an increase of the oxygen amount in the reaction feed stream, while CO selectivity decreases. The same behavior has been observed with different types of catalysts in several reports in the literature [36] With $\mathrm{O}_{2} / \mathrm{CO}$ ratios $1.49,0.75$ and 0.46 , the $\mathrm{CO}$ conversions are $\sim 99 \%, 99 \%$ and $84 \%$ at $100^{\circ} \mathrm{C}$, respectively. The selectivity at the same temperature was $37 \%, 65 \%$, and $97 \%$ for the $\mathrm{O}_{2} / \mathrm{CO}$ ratios of $1.49,0.75$ and 0.46 , respectively. According to the results, 0.75 was selected as the best $\mathrm{O}_{2} / \mathrm{CO}$ ratio needed for oxidizing $\mathrm{CO}$ with high activity and minimal loss of hydrogen.

It must be considered that the gases analyzed in PROX-CO reactor contained water and $\mathrm{CO}_{2}$. According to the products distribution in the effluent stream of the SRE reactor, the composition was $60 \% \mathrm{H}_{2}, 1-2 \% \mathrm{CO}, 10-20 \% \mathrm{CO}_{2}$ and 2$10 \% \mathrm{H}_{2} \mathrm{O}$ in volume. Jardim et al. [36] reported a negative effect of water and $\mathrm{CO}_{2}$ on catalytic behavior due to a competitive adsorption on the active sites and to the formation of surface carbonaceous deposits. 


\section{TECCIENCLA}
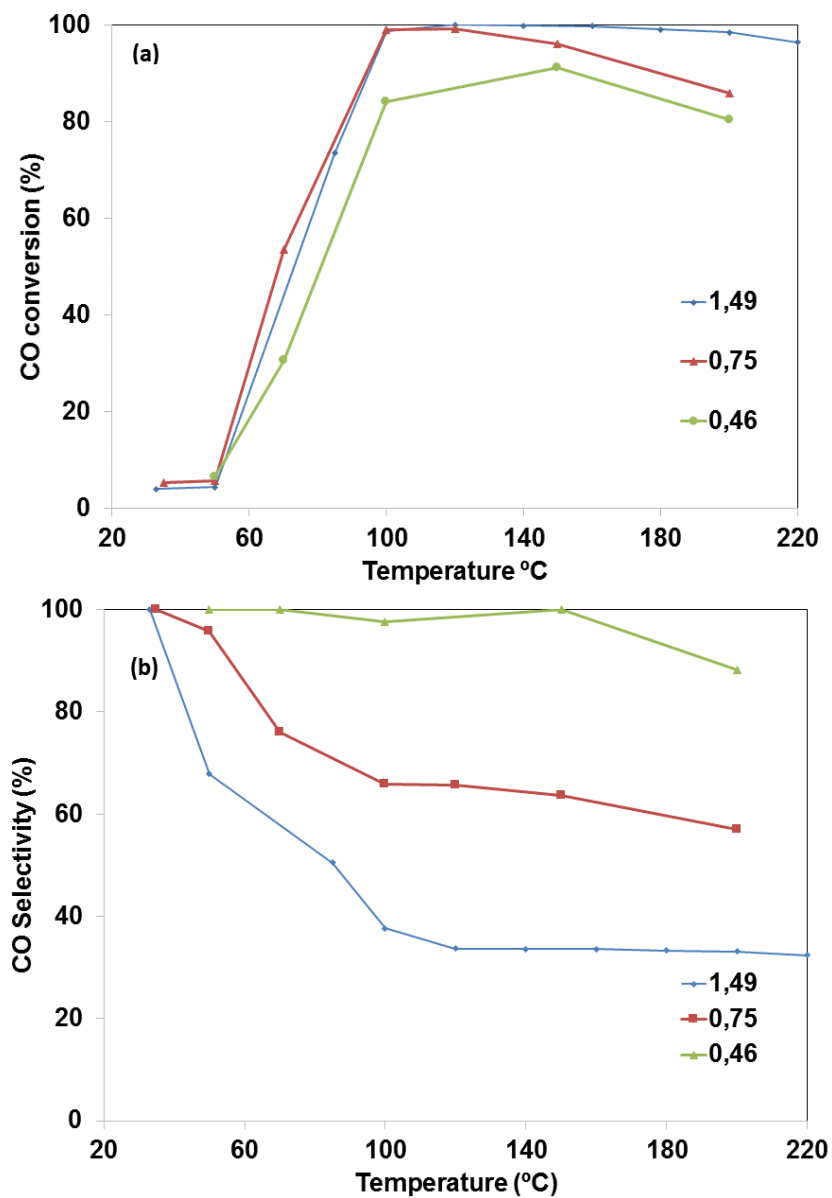

Figure 6 Effect of $\mathrm{O}_{2}$ concentration in reactant gas. Over $\mathrm{Au}-\mathrm{CeO}_{2}-\mathrm{ZrO}_{2}$ (c) catalyst. Reactant composition: $2 \% \mathrm{CO}$. $0.5-2 \% \mathrm{O}_{2} .50 \% \mathrm{H}_{2}$ and helium. Selectivity (dotted line); $\mathrm{CO}$ conversion (full line).

\subsection{Stability tests}

Stability is an important characteristic of any catalyst that determines its efficient use in a reaction. Figures $7 \mathrm{a}$ and $7 \mathrm{~b}$ show the stability tests in SRE and PROX-CO, respectively. As explained before, the test was performed using two in series reactors. In the first one, SRE was carried out using $7 \mathrm{Ni}-\mathrm{CZ}$ as catalyst and, then, effluent gas pass through the second reactor containing the catalyst $2 \mathrm{Au}-\mathrm{CZ}$, where PROX-CO reaction is carried out.

The results show that $7 \mathrm{Ni}-\mathrm{CZ}$ and $2 \mathrm{Au}-\mathrm{CZ}$ are active and selective for SRE and PROX-CO, respectively, during the time of the test. According to the results, the produced hydrogen (5.4 mole of hydrogen per mole of ethanol consumed) accomplish the requirements for use in a fuel cell, since CO conversion was about $100 \%$ with low hydrogen consumption
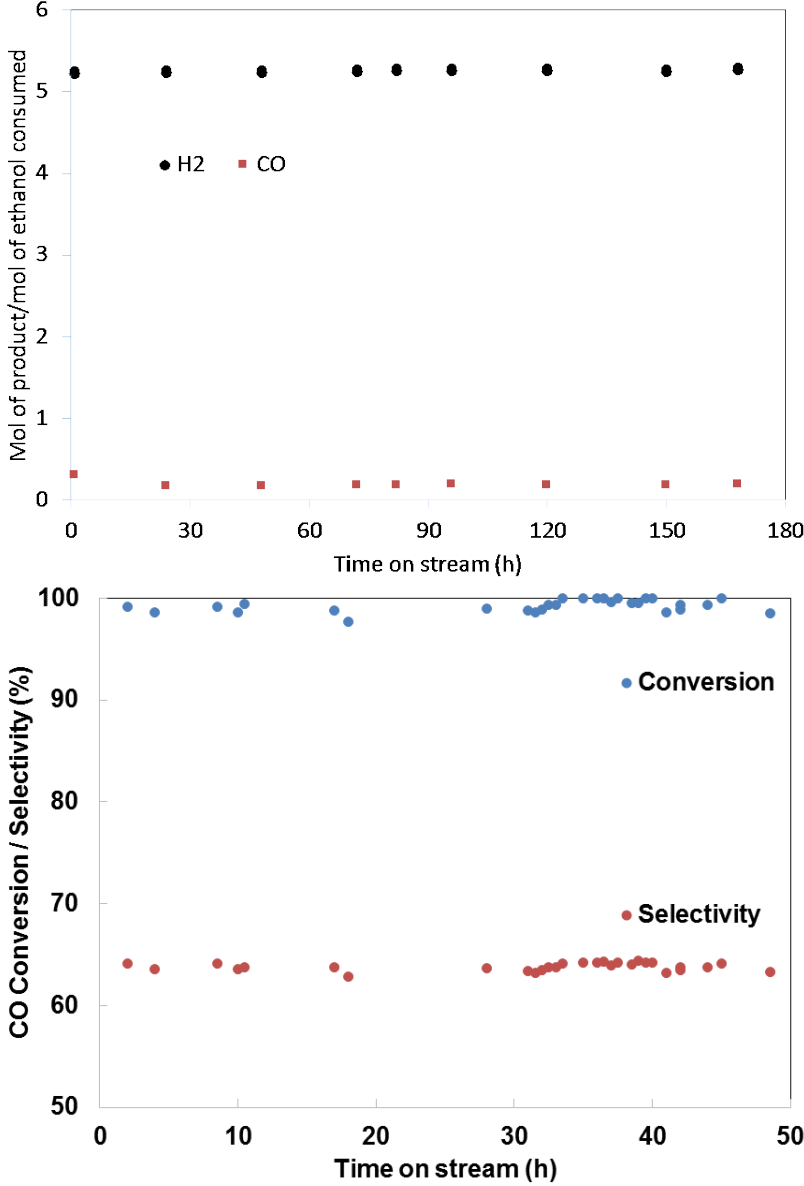

Figure 7 Stability test over $7 \mathrm{Ni}-\mathrm{CZ}$ on the Steam reforming of ethanol (a) and 2Au-CZ on PROX-CO (b) catalyst. Reforming reaction condition: $3.5 \mathrm{~mol} \%$ ethanol $21 \mathrm{~mol} \%$.

\section{Conclusions}

The steam reforming of ethanol and subsequent PROX-CO was accomplished over a $\mathrm{Ni}-\mathrm{CZ}$ and $\mathrm{Au}-\mathrm{CZ}$, respectively. The variation of the initial concentrations of water showed a complete ethanol conversion and a maximum $\mathrm{H}_{2} / \mathrm{CO}$ ratio, when 25 mole $\% \mathrm{H}_{2} \mathrm{O}$ and 4 mole $\% \mathrm{C}_{2} \mathrm{H}_{5} \mathrm{OH}(\mathrm{S} / \mathrm{E}=7)$ were used in the SRE over $7 \mathrm{Ni}-\mathrm{CZ}$ at $700^{\circ} \mathrm{C}$. The effect of the $\mathrm{O}_{2}$ concentration in the feed on Au-CZ catalysts showed that $\mathrm{O}_{2} / \mathrm{CO}$ ratio 0.75 is the suitable for higher oxidation of $\mathrm{CO}$ without lower hydrogen consumption.

The SRE stability was assessed under the selected conditions at $600^{\circ} \mathrm{C}$, during more than $160 \mathrm{~h}$ on stream, obtaining ethanol conversions above $99 \%$ during the entire test and $\mathrm{H}_{2}$ productivity close to the ideal, 5.4 mole of hydrogen per mole of ethanol consumed. The PROX-CO test shows CO conversion of about $99 \%$ and selectivity around $64 \%$ for 50 $\mathrm{h}$ on stream. 
The TPR, XRD and SEM characterization techniques confirm that the good metal dispersion and the promoted strong interaction in the $\mathrm{Ni}-\mathrm{CZ}$ and $\mathrm{Au}-\mathrm{CZ}$ catalysts contribute to the high activity selectivity and stability of the catalyst.

\section{References}

[1] N. Lior, "Energy resources and use: The present situation and possible paths to the future," Energy, vol. 33, no. 6, pp. 842-857, Jun. 2008.

[2] M. Ni, D. Y. C. Leung, and M. K. H. Leung, "A review on reforming bio-ethanol for hydrogen production," Int. J. Hydrogen Energy, vol. 32, pp. 3238-3247, 2007.

[3] M. Ni, D. Y. C. Leung, M. K. H. Leung, and K. Sumathy, "An overview of hydrogen production from biomass," Fuel Process. Technol., vol. 87, pp. 461-472, 2006.

[4] K. Show, D. Lee, and Z. Zhang, "Biofuels," pp. 467-479, 2011

[5] Haryanto, S. Fernando, N. Murali, and S. Adhikari, "Current status of hydrogen production techniques by steam reforming of ethanol: A review," Energy and Fuels, vol. 19, no. 10, pp. 2098-2106, 2005.

[6] M. Cobo, D. Pieruccini, R. Abello, L. Ariza, L. F. Córdoba, and J. a. Conesa, "Steam reforming of ethanol over bimetallic $\mathrm{RhPt} / \mathrm{La} 2 \mathrm{O} 3$ : Long-term stability under favorable reaction conditions," Int. J. Hydrogen Energy, vol. 38, pp. 5580-5593, 2013.

[7] P. Biswas and D. Kunzru, "Oxidative steam reforming of ethanol over $\mathrm{Ni} / \mathrm{CeO} 2-\mathrm{ZrO} 2$ catalyst," Chem. Eng. J., vol. 136, pp. 41-49, 2008.

[8] G. Manzolini and S. Tosti, "Hydrogen production from ethanol steam reforming: energy efficiency analysis of traditional and membrane processes," Int. J. Hydrogen Energy, vol. 33, no. 20, pp. $5571-5582,2008$.

[9] A. Arango-Díaz, E. Moretti, A. Talon, L. Storaro, M. Lenarda, P. Núñez, J. Marrero-Jerez, J. Jiménez-Jiménez, A. Jiménez-López, and E. Rodríguez-Castellón, "Preferential $\mathrm{CO}$ oxidation $(\mathrm{CO}$ PROX) catalyzed by $\mathrm{CuO}$ supported on nanocrystalline $\mathrm{CeO} 2$ prepared by a freeze-drying method," Appl. Catal. A Gen., vol. 477, pp. 54-63, May 2014.

[10] Á. Reyes-Carmona, A. Arango-Díaz, E. Moretti, A. Talon, L. Storaro, M. Lenarda, A. Jiménez-López, and E. RodríguezCastellón, " $\mathrm{CuO} / \mathrm{CeO} 2$ supported on $\mathrm{Zr}$ doped $\mathrm{SBA}-15$ as catalysts for preferential CO oxidation (CO-PROX)," J. Power Sources, vol. 196, no. 9, pp. 4382-4387, May 2011.

[11] S. M. de Lima, R. C. Colman, G. Jacobs, B. H. Davis, K. R. Souza, A. F. F. de Lima, L. G. Appel, L. V. Mattos, and F. B. Noronha, "Hydrogen production from ethanol for PEM fuel cells. An integrated fuel processor comprising ethanol steam reforming and preferential oxidation of CO," Catal. Today, vol. 146, pp. 110-123, 2009.

[12] D. R. Sahoo, S. Vajpai, S. Patel, and K. K. Pant, "Kinetic modeling of steam reforming of ethanol for the production of hydrogen over Co/Al2O3 catalyst," Chem. Eng. J., vol. 125, pp. 139-147, 2007.

[13] P. Biswas and D. Kunzru, "Steam reforming of ethanol for production of hydrogen over $\mathrm{Ni} / \mathrm{CeO} 2-\mathrm{ZrO} 2$ catalyst: Effect of support and metal loading," Int. J. Hydrogen Energy, vol. 32, pp. 969-980, 2007.

[14] J. Fonseca, S. Royer, N. Bion, L. Pirault-Roy, M. do C. Rangel, D. Duprez, and F. Epron, "Preferential CO oxidation over nanosized gold catalysts supported on ceria and amorphous ceria - alumina," "Applied Catal. B, Environ., vol. 128, pp. 10-20, 2012.

[15] T. Mondal, K. K. Pant, and A. K. Dalai, "Catalytic oxidative steam reforming of bio-ethanol for hydrogen production over Rh promoted $\mathrm{Ni} / \mathrm{CeO} 2-\mathrm{ZrO} 2$ catalyst," Int. J. Hydrogen Energy, vol. 40, no. 6, pp. 2529-2544, 2015.

[16] O. H. Laguna, M. A. Centeno, G. Arzamendi, L. M. Gandía, F. Romero-Sarria, and J. A. Odriozola, "Iron-modified ceria and
$\mathrm{Au} /$ ceria catalysts for total and preferential oxidation of CO (TOX and PROX)," Catal. Today, vol. 157, no. 1-4, pp. 155-159, Nov. 2010 .

[17] C. Diagne, H. Idriss, K. Pearson, M. A. Gómez-García, and A. Kiennemann, "Efficient hydrogen production by ethanol reforming over $\mathrm{Rh}$ catalysts. Effect of addition of $\mathrm{Zr}$ on $\mathrm{CeO} 2$ for the oxidation of CO to CO2," Comptes Rendus Chim., vol. 7, pp. 617-622, 2004.

[18] E. Moretti, L. Storaro, a. Talon, S. Chitsazan, G. Garbarino, G. Busca, and E. Finocchio, "Ceria-zirconia based catalysts for ethanol steam reforming," Fuel, vol. 153, pp. 166-175, 2015.

[19] H. Muroyama, R. Nakase, T. Matsui, and K. Eguchi, "Ethanol steam reforming over Ni-based spinel oxide,” Int. J. Hydrogen Energy, vol. 35, no. 4, pp. 1575-1581, 2010

[20] J. Sun, X. P. Qiu, F. Wu, and W. T. Zhu, "H2 from steam reforming of ethanol at low temperature over $\mathrm{Ni} / \mathrm{Y} 2 \mathrm{O} 3$ and $\mathrm{Ni} / \mathrm{La} 2 \mathrm{O} 3$ catalysts for fuel-cell application,” Int. J. Hydrogen Energy, vol. 30, pp. 437445, 2005

[21] W. S. Dong, H. S. Roh, K. W. Jun, S. E. Park, and Y. S. Oh, "Methane reforming over $\mathrm{Ni} / \mathrm{Ce}-\mathrm{ZrO} 2$ catalysts: Effect of nickel content," Appl. Catal. A Gen., vol. 226, pp. 63-72, 2002.

[22] E. B. Pereira, N. Homs, S. Martí, J. L. G. Fierro, and P. Ramírez de la Piscina, "Oxidative steam-reforming of ethanol over $\mathrm{Co} / \mathrm{SiO} 2, \mathrm{Co}-$ $\mathrm{Rh} / \mathrm{SiO} 2$ and $\mathrm{Co}-\mathrm{Ru} / \mathrm{SiO} 2$ catalysts: Catalytic behavior and deactivation/regeneration processes," J. Catal., vol. 257, pp. 206214, 2008

[23] M. Araque, J. C. Vargas, Y. Zimmermann, and A.-C. Roger, "Study of a CeZrCoRh mixed oxide for hydrogen production by ethanol steam reforming," Int. J. Hydrogen Energy, vol. 36, pp. 1491-1502, 2011.

[24] M. Dan, M. Mihet, Z. Tasnadi-Asztalos, A. Imre-Lucaci, G. Katona, and M. D. Lazar, "Hydrogen production by ethanol steam reforming on nickel catalysts: Effect of support modification by $\mathrm{CeO} 2$ and La2O3," Fuel, vol. 147, pp. 260-268, 2015.

[25] R. Trane-Restrup, S. Dahl, and a. D. Jensen, "Steam reforming of ethanol: Effects of support and additives on Ni-based catalysts," Int J. Hydrogen Energy, vol. 38, no. 35, pp. 15105-15118, 2013

[26] O. H. Laguna, W. Y. Hernández, G. Arzamendi, L. M. Gandía, M. a. Centeno, and J. a. Odriozola, "Gold supported on $\mathrm{CuOx} / \mathrm{CeO} 2$ catalyst for the purification of hydrogen by the $\mathrm{CO}$ preferential oxidation reaction (PROX)," Fuel, vol. 118, pp. 176-185, 2014.

[27] M. Haruta and M. Daté, "Advances in the catalysis of Au nanoparticles,” Appl. Catal. A Gen., vol. 222, pp. 427-437, 2001.

[28] M. a. Centeno, M. Paulis, M. Montes, and J. a. Odriozola, "Catalytic combustion of volatile organic compounds on $\mathrm{Au} / \mathrm{CeO} 2 / \mathrm{Al} 2 \mathrm{O} 3$ and $\mathrm{Au} / \mathrm{Al} 2 \mathrm{O} 3$ catalysts," Appl. Catal. A Gen., vol. 234, pp. 65-78, 2002.

[29] L. Guczi, D. Horváth, Z. Pászti, and G. Petõ, "Effect of treatments on gold nanoparticles: Relation between morphology, electron structure and catalytic activity in CO oxidation," Catal. Today, vol. 72, pp. 101-105, 2002.

[30] J.-D. Grunwaldt, C. Kiener, C. Wögerbauer, and A. Baiker, "Preparation of Supported Gold Catalysts for Low-Temperature CO Oxidation via 'Size-Controlled' Gold Colloids,” J. Catal., vol. 181, pp. 223-232, 1999

[31] A. Luengnaruemitchai, S. Chawla, and R. Wanchanthuek, "The catalytic performance of $\mathrm{Au} / \mathrm{La}-\mathrm{CeOx}$ catalyst for PROX reaction in H2 rich stream,” Int. J. Hydrogen Energy, vol. 39, no. 30, pp. 16953 16963, 2014.

[32] F. Ocampo, B. Louis, L. Kiwi-Minsker, and A. C. Roger, "Effect of $\mathrm{Ce} / \mathrm{Zr}$ composition and noble metal promotion on nickel based CexZr1-xO2 catalysts for carbon dioxide methanation,” Appl. Catal. A Gen., vol. 392, no. 1-2, pp. 36-44, 2011.

[33] F. Ocampo, B. Louis, and A.-C. Roger, "Methanation of carbon dioxide over nickel-based $\mathrm{Ce} 0.72 \mathrm{Zr} 0.28 \mathrm{O} 2$ mixed oxide catalysts prepared by sol-gel method," Appl. Catal. A Gen., vol. 369, pp. 90 96, 2009.

[34] J. C. Vargas, S. Libs, A.-C. Roger, and A. Kiennemann, "Study of Ce-Zr-Co fluorite-type oxide as catalysts for hydrogen production by steam reforming of bioethanol," Catal. Today, vol. 107-108, pp. $417-425,2005$ 


\section{TECCIENCIA}

[35] J. Lin and B. Wan, "Effects of preparation conditions on gold / Ytype zeolite for CO oxidation,” Appl. Catal. B Environ., vol. 41, pp. 83-95, 2003.

[36] E. D. O. Jardim, S. Rico-Francés, F. Coloma, E. V. RamosFernández, J. Silvestre-Albero, and A. Sepúlveda-Escribano, "Superior performance of gold supported on doped $\mathrm{CeO} 2$ catalysts for the preferential CO oxidation (PROX)," Appl. Catal. A Gen., vol. 487, pp. 119-129, 2014

[37] O. H. Laguna, F. Romero Sarria, M. A. Centeno, and J. A. Odriozola, "Gold supported on metal-doped ceria catalysts ( $\mathrm{M}=\mathrm{Zr}, \mathrm{Zn}$ and $\mathrm{Fe})$ for the preferential oxidation of CO (PROX)," J. Catal., vol. 276, no. 2, pp. 360-370, Dec. 2010.

[38] S. Sun, W. Yan, P. Sun, and J. Chen, "Thermodynamic analysis of ethanol reforming for hydrogen production," Energy, vol. 44, no. 1, pp. 911-924, 2012

[39] M. Verónica, B. Graciela, A. Norma, and L. Miguel, "Ethanol steam reforming using $\mathrm{Ni}(\mathrm{II})-\mathrm{Al}(\mathrm{III})$ layered double hydroxide as catalyst precursor. Kinetic study," Chem. Eng. J., vol. 138, pp. 602-607, 2008.

[40] A. Luengnaruemitchai, S. Osuwan, and E. Gulari, "Selective catalytic oxidation of $\mathrm{CO}$ in the presence of $\mathrm{H} 2$ over gold catalyst," Int. J. Hydrogen Energy, vol. 29, pp. 429-435, 2004.

[41] R. E. Ramírez-Garza, B. Pawelec, T. A. Zepeda, and A. MartínezHernández, "Total CO oxidation over Fe-containing Au / HMS catalysts : Effects of gold loading and catalyst pretreatment," Catal. Today, vol. 172, pp. 95-102, 2011. 